\title{
Model Komunikasi Pemeriksaan Dalam Sidang Agenda Pembuktian Perkara di Pengadilan
}

\author{
Aan Widodo \\ Fakultas Ilmu Komunikasi, Universitas Bhayangkara Jakarta Raya \\ Kampus II Jalan Perjuangan Marga Mulya Bekasi Utara, Bekasi, Indonesia \\ aan.widodo@dsn.ubharajaya.ac.id
}

Masuk tanggal : 08-07-2020, revisi tanggal : 13-08-2020, diterima untuk diterbitkan tanggal : 10-09-2020

\begin{abstract}
An examination of the case is conducted to reveal evidence and information that the defendant is considered to have committed a criminal offense that caused the victim to loss, and that the victim is the party who was harmed by the defendant. Case examination through communication activities in the case examination agenda session as examination communication. This article aims to find a model of examination communication in the agenda of proving a case in court. The concept in this research is Examination Communication and Communication Ethnography. The research method used is descriptive qualitative research. Researchers interviewed 15 informants, observed 3 criminal cases, and documented the research. The results of this study indicate that the audit communication activities at the Court take place in the courtroom. The case evidence agenda forms three models of examination communication based on communication participants, namely (1) the law enforcement communication model with the defendant, namely the communication activities of judges, prosecutors, and legal advisers with the defendant (2) law enforcer communication model with victims, namely communication activities of judges, legal advisers, public prosecutors with victims (3) the model of communication between law enforcers and witnesses, namely the communication activities of judges, legal advisers, prosecutors with defendants. In practice, communication activities for the examination of defendants, victims and witnesses can be carried out simultaneously, which is called the cross examination communication model. The crossexamination communication model is carried out to verify and confirm evidence, the information provided by the accused, witnesses and victims simultaneously.
\end{abstract}

Keywords: communication examination, communication model examination, crossexamination communication, the agenda of the case investigation, the trial communication

\begin{abstract}
Abstrak
Pemeriksaan perkara dilakukan untuk mengungkap bukti dan informasi bahwa terdakwa dianggap melakukan tindak pidana yang merugikan korban, dan bahwa korban adalah pihak yang dirugikan oleh terdakwa. Pemeriksaan perkara melalui kegiatan komunikasi dalam sidang agenda pemeriksaan perkara sebagai komunikasi pemeriksaan. Artikel ini bertujuan untuk menemukan model komunikasi pemeriksaan dalam agenda pembuktian perkara di Pengadilan. Konsep dalam penelitian ini adalah Komunikasi Pemeriksaan dan Etnografi Komunikasi. Metode penelitian yang digunakan adalah penelitian deskriptif kualitatif. Peneliti mewawancarai 15 informan, mengamati 3 kasus pidana, dan mendokumentasikan penelitian tersebut. Hasil penelitian ini menunjukkan bahwa kegiatan komunikasi pemeriksaan di pengadilan berlangsung di ruang sidang persidangan. Agenda
\end{abstract}


pembuktian perkara membentuk tiga model komunikasi pemeriksaan berdasarkan peserta komunikasi, yaitu (1) model komunikasi penegak hukum dengan terdakwa, yaitu kegiatan komunikasi para hakim, jaksa, dan penasihat hukum dengan terdakwa (2) model komunikasi penegak hukum dengan korban, yakni kegiatan komunikasi hakim, penasihat hukum, penuntut umum dengan korban (3) model komunikasi antara penegak hukum dan saksi yakni kegiatan komunikasi hakim, penasihat hukum, jaksa, dengan terdakwa. Dalam praktiknya, kegiatan komunikasi pemeriksaan terdakwa, korban, dan saksi dapat dilakukan secara bersamaan, yang disebut model komunikasi pemeriksaan silang. Model komunikasi pemeriksaan silang dilakukan untuk memverifikasi dan mengkonfirmasi bukti, informasi yang diberikan oleh terdakwa, saksi dan korban secara bersamaan.

Kata Kunci: agenda pemeriksaan perkara, komunikasi pemeriksaan, komunikasi pemeriksaan silang, komunikasi persidangan, model komunikasi pemeriksaan

\section{Pendahuluan}

Salah satu tahapan dalam upaya penegakan hukum di Indonesia ialah melalui sidang atau lazim disebut persidangan. Persidangan merupakan pertemuan untuk membicarakan sesuatu (Kebudayaan, 2020). Persidangan membahas berbagai perkara, dalam konteks hukum pidana, perkara yang dibahas adalah persoalan tindak kejahatan yang diduga telah dilakukan oleh tersangka (Samosir, 2013).

Persidangan menjadi bagian dari upaya penegakan hukum bagi terdakwa dan korban melalui pembuktian perkara. Pembuktian dimaksud guna menemukan kebenaran materiil tentang tersangka suatu tindak pidana, serta kerugian yang dialami korban. Persidangan menjadi inti dari pembuktian perkara dengan melibatkan terdakwa, korban, saksi dengan tujuan pembuktian kebenaran dan keadilan oleh penegak hukum (Fuady, 2020; Hiariej, 2012)

Penegak hukum berupaya memastikan dan membuktikan bahwa suatu tindak pidana benar-benar terjadi dan bahwa terdakwa adalah orang yang melakukan kejahatan tertentu setelah kasus terdakwa diperiksa di Pengadilan. Dalam perspektif hukum persidangan dibagi menjadi beberapa agenda persidangan, salah satu agenda umumnya dikenal sebagai agenda pembuktian perkara. Agenda ini adalah agenda memeriksa korban, terdakwa, saksi, dan bukti lain sebagai dasar bagi hakim untuk mendapatkan keyakinan dalam menghukum seorang terdakwa. Dari perspektif komunikasi, persidangan adalah konteks komunikasi untuk mencapai keadilan, Kathryn Meagan Cowles (2011) menyebutnya courtroom communication atau communication in the courtroom (Chen, 2015; Cowles \& Cowles, 2011). Courtroom communication (Komunikasi di ruang sidang) adalah konteks komunikasi dalam persidangan, yang terdiri dari aktor komunikasi yang memiliki peran dan tujuan, kepentingan, dan situasi dalam setiap proses persidangan.

Sebagai bagian dari agenda persidangan dalam proses persidangan, sidang agenda pembuktian perkara dalam kegiatan dan proses komunikasi melibatkan penegak hukum, saksi dan terdakwa korban. Komunikasi yang terjadi pada persidangan agenda pembuktian ini oleh Matoesian (2017), Grażyna Anna Bednarek (2014) Joanne Morrison, Rachel Forrester-Jones, Jill Bradshaw, Glynis 
Aan Widodo: Model Komunikasi Pemeriksaan Dalam Sidang Agenda Pembuktian Perkara di Pengadilan

Murphy (2019) disebut komunikasi pemeriksaan (communication examination) (Bednarek, 2014; Matoesian, 2017; Morrison et al., 2019). Selain communication examination, konteks komunikasi pemeriksaan perkara dalam persidangan juga dikenal dengan istilah lain yakni komunikasi investigasi (investigations communication). (Field., 2018; Matoesian, 2017; Roberts, 2011).

Komunikasi pemeriksaan adalah bentuk komunikasi yang merupakan kunci keberhasilan pemeriksaan perkara. Studi O’Neill M., Milne B. (2014) dengan judul Success Within Criminal Investigations: Is Communication Still a Key Component? Mengungkapkan bahwa komunikasi menjadi kunci dalam keberhasilan pemeriksaan perkara. Keterampilan komunikasi diperlukan, yang melibatkan berbagai komponen, cara mengajukan pertanyaan dan jawaban, cara menilai berdasarkan pengamatan, bagaimana memberikan evaluasi terhadap bukti tertentu (O’Neill M., Milne B, 2014). Communication examination ataupun communication investigations memiliki kriteria, (1) terjadi dalam agenda persidangan, (2) berlangsung dalam agenda pembuktian perkara, (3) melibatkan penegak hukum, terdakwa, korban, dan saksi, (4) bertujuan untuk pembuktian, dilakukan dengan memeriksa bukti, keterangan terdakwa, saksi dan ahli, (5) Hasil dari pemeriksaan dilakukan guna pertimbangan hakim dan penegak hukum menjatuhkan hukuman pada terdakwa (Bednarek, 2014; Field., 2018; Gehl \& Plecas, 2016; Matoesian, 2017; Roberts, 2011).

Fenomena komunikasi pemeriksaan berdasar uraian di atas, tergambar dalam persidangan di pengadilan Indonesia, dan di agenda pembuktian perkara di pengadilan Negeri Jakarta Pusat. Pengamatan yang dilakukan peneliti dalam kasus pidana pencurian yang dilakukan terdakwa $\mathrm{H}$, sidang agenda pembuktian perkara menghadirkan terdakwa $\mathrm{H}$, sebagai orang yang diduga bersalah, menghadirkan saksi-saksi diantaranya saksi dari K dan J pihak penasihat hukum dan saksi S dan $\mathrm{H}$ dari pihak penuntut umum. Sidang terjadi beberapa kali, persidangan dilakukan dengan pemisahan agenda pemeriksaan $\mathrm{H}, \mathrm{S}$ dan J. Menurut informan, setelah pemeriksaan masing-masing tersebut terjadi pemeriksaan secara bersama. Ketika pemeriksaan perkara ditunda, maka akan berimplikasi pada lamanya persidangan, sementara apabila terdakwa tidak kooperatif maka akan berimplikasi pada putusan yang akan diberikan berdasar tuntutan yang diberikan oleh penuntut umum. Artinya pemeriksaan perkara menjadi bagian penting dalam menentukan besaran hukuman yang akan diterima.

Indonesia sendiri sebagai negara yang menganut sistem hukum civil law menjadikan pembuktian perkara di Pengadilan sebagai wujud penegakan hukum, yang mencerminkan berbagai proses dan bentuk komunikasi yang terjadi dalam sistem hukum yang sama. Yusti Probowati R (2006) mengungkapkan bahwa pengambilan keputusan dalam sebuah kelompok persidangan ditentukan dari bagaimana kelompok tersebut saling berkomunikasi. Komunikasi masing-masing pihak menjadi faktor pendukung dalam tercapainya keadilan terdakwa, sebaliknya akan menjadi hambatan pada satu-sama lainnya. (R, 2016)

Dalam konteks komunikasi pengadilan, baik komunikasi dalam persidangan maupun komunikasi pemeriksaan terdapat beberapa hal faktor yang merupakan bagian dari komponen komunikasi dalam konteks komunikasi. Komponen komunikasi menyangkut penegak hukum, terdakwa, saksi dan 
keterampilan komunikasi yang dimiliki, tujuan komunikasi dilakukan, serta pesanpesan yang disampaikan sebagai alat bukti dalam persidangan. Hadirnya pihakpihak yang terlibat dalam komunikasi pemeriksaan, perbedaan peran kepentingan, waktu dan keterampilan komunikasi yang dimiliki menjadi aspek komunikasi yang tergambar dalam agenda pemeriksaan perkara. Aspek-aspek tersebut, bila meminjam pemetaan Dell Hymes mengenai komponen komunikasi dalam sebuah peristiwa komunikasi terdiri dari Setting and Scene, Partisipant, Ends, Act, Key, Intrumentalities, Norm, dan Genre disebut teori etnografi komunikasi. Teori Etnografi Komunikasi berpandangan bahwa Pemolaan (patterning) umumnya terjadi pada semua tingkat komunikasi: masyarakat, kelompok, dan individu. (Gabbert et al., 2015; Haryono, 2015; Littlejohn \& Foss, 2009).

Dalam praktiknya, hingga persidangan keputusan terdapat tiga pihak penegak hukum yakni pihak hakim, penasihat hukum, penuntut umum. Dan pihak yang diperiksa yakni korban, terdakwa atau saksi dalam hal ini menjadi bagian dari pihak yang dapat meringankan ataupun memberatkan hukuman yang dapat diterima terdakwa, dimana penegak hukum dan terdakwa, korban dan saksi masuk dalam kategori partisipan komunikasi. Keterhubungan pihak dan komponen komunikasi, menjadi satu aktivitas budaya yang membentuk model komunikasi. Menurut West and Turner (2011) model komunikasi ialah sistem yang terdiri dari berbagai berbagai komponen komunikasi dan proses komunikasi, selain dari pelaku komunikasi/partisipan komunikasi model komunikasi juga dapat dikategori berdasar model pesan (Hadiprashada et al., 2019; Kristofer \& Susanto, 2019).

Melihat persidangan dalam sudut pandang komunikasi telah dilakukan Marcela Fărcaşiu (2013) persidangan di Pengadilan Romania dari sudut lingustik yang menyatakan bahwa pengaturan ruang dan penggunaan bahasa penting dalam persidangan (FĂRCAŞIU, 2013). Sementara Gavin Oxburgh (2016) melalui komunikasi dalam konteks hukum menguraikan bahwa komunikasi pemeriksaan dalam persidangan, menghadirkan dan memeriksa saksi sebagai upaya mencari kebenaran melalui komunikasi (Matoesian, 2017). Kedua riset itu melihat persidangan sebagai bentuk fenomena komunikasi dari sudut pandang persidangan sebagai konteks, yang sejalan dengan penelitian ini.

Komunikasi pemeriksaan pada sidang agenda pembuktian pada pengadilan sebagai lembaga penegak hukum menjadi bagian dari upaya penegakan hukum yang memunculkan beragam bentuk komunikasi diantaranya pemeriksaan dan persidangan (Roberts, 2011), komunikasi interview saksi (Brewer et al., 2018), komunikasi pemeriksaan oleh jaksa, (Field., 2018), komunikasi hakim dengan penasihat hukum (Aceron, 2015). Penelitian-penelitian tersebut menjelaskan kedudukan penegak hukum dan aktivitas komunikasi yang dilakukan penting, sebab masing-masing pihak membawa kepentingan dan tujuan, yang berpengaruh pada hasil atau keputusan persidangan. Artinya bila komunikasi pemeriksaan tidak dilakukan dengan optimal, maka keputusan hukuman yang akan dihasilkan bisa saja tidak optimal, yang disebabkan kurang tergalinya informasi tentang perkara itu.

Pentingnya komunikasi pemeriksaan dilakukan, karena hasil dari komunikasinya akan memengaruhi putusan, persepsi anggota, dan cara menerima dan memperoleh informasi diruang sidang. (Cowles \& Cowles, 2011) dan banyak 
Aan Widodo: Model Komunikasi Pemeriksaan Dalam Sidang Agenda Pembuktian Perkara di Pengadilan

faktor yang mendukung diantaranya kemampuan komunikasi penegak hukum dan model komunikasi yang diterapkan. Chen (2015) dalam risetnya mengungkapkan bahwa dalam persidangan penegak hukum mengkomunikasikan semua fakta dari sebuah kasus bersamaan dengan argument dan bukti, melalui kemampuan komunikasi verbal maupun nonverbal yang dimiliki yang mendukung keberhasilan komunikasi (Chen, 2015). Greacen Associates (2008) menegaskan kemampuan komunikasi dalam memperoleh informasi, mengajukan pertanyaan, meringkas dan memperhatikan proses persidangan, serta pemahaman akan substansi hukum (Network, 2008). Maka dari itu, Komunikasi, kemampuan komunikasi, dan model komunikasi yang diterapkan dalam pemeriksaan perkara penting diterapkan termasuk dalam persidangan pengadilan Indonesia.

Komunikasi pemeriksaan berlangsung dengan teknik interview ataupun interogasi (Archer, 2011; Gabbert et al., 2015; Morrison et al., 2019; Setyo, 2013). Interview ataupun interogasi terjadi pada pemeriksaan terdakwa, korban, dan saksi (Brewer et al., 2018; Groome \& Eysenck, 2016). Interview ataupun interogasi dalam persidangan dapat dilakukan penegak hukum dalam waktu yang bersamaan ataupun terpisah, misalnya antara pemeriksaan saksi dan pemeriksaan terdakwa diagenda dan waktu yang berbeda, termasuk saksi yang dihadirkan masing-masing pihak, sehingga akan dilakukan pemeriksaan silang (Archer, 2011; Gabbert et al., 2015). Secara umum model komunikasi dalam persidangan dilihat dari sudut pandang pelaku, peran dan tujuan merujuk pada dua model komunikasi yaitu model komunikasi penegak hukum dalam persidangan dan model komunikasi antar penegak hukum dalam persidangan (Widodo, 2019), selain itu berbentuk pola komunikasi antara penasihat hukum dengan terdakwa (Widodo et al., 2018), dan pola interupsi dalam persidangan (Widodo et al., 2019). Namun model komunikasi yang dilihat dari salah satu proses persidangan yang menjadi inti dari pemeriksaan menjadi focus pembeda kebaruan, sehingga penelitian menjadi penting dilakukan, selain menemukan model dalam konteks persidangan pidana juga melengkapi berbagai model komunikasi yang sudah ada, dengan harapan menguraikan persidangan dari sudut pandang keilmuan komunikasi melalui komunikasi pemeriksaan dan komponen komunikasi, sehingga dapat berguna bagi penegak hukum, dan bidang hukum dalam memahami proses dan model komunikasi pemeriksaan dalam persidangan dalam upaya membentuk komunikasi yang efektif.

\section{Metode Penelitian}

Penelitian dilakukan menggunakan metode penelitian deskriptif kualitatif. Subjek penelitian ini adalah orang-orang yang terlibat dalam sidang agenda pemeriksaan perkara, sementara objek dalam penelitian ini adalah aktivitas komunikasi pemeriksaan yang dilakukan pihak-pihak yang terlibat dalam persidangan yang terdiri dari penegak hukum (hakim, penuntut umum, penasihat hukum), saksi dan terdakwa. Pemilihan sidang agenda pemeriksaan perkara dilakukan karena pembuktian perkara merupakan bagian inti dalam menggali informasi dari pihak-pihak yang bersentuhan langsung dengan perkara. 
Data penelitian diperoleh dengan melakukan Teknik pengumpulan data sebagaimana diungkapkan Mulyana (2013) yakni wawancara, observasi partisipasi, dan studi dokumentasi (Mulyana, 2017). Wawancara dilakukan pada 15 informan penelitian, observasi dilakukan pada 3 persidangan perkara pidana di ruang sidang pengadilan yakni persidangan terdakwa SK, terdakwa JS, dan SN. Sementara Teknik keabsahan data dalam penelitian ini dilakukan dengan Teknik triangulasi sumber. Pemilihan Pengadilan Negeri Jakarta Pusat sebagai lokasi penelitian, disebabkan Pengadilan Negeri Jakarta Pusat sebagai pengadilan terbesar dan salah satu dari lima peradilan percontohan dari aspek fisik, jumlah perkara dan layanan peradilan berdasarkan pemantauan Badan Peradilan Umum Mahkamah Agung Republik Indonesia tahun 2020.

Data yang telah diperoleh melalui pengumpulan data, kemudian penulis olah melalui teknik analisis data, yakni reduksi data, deskripsi data, verifikasi dan kesimpulan penelitian (Creswell, 2010). Penulis melakukan pemilihan data yang didasarkan pada kategori (reduksi data). Data yang direduksi berupa data hasil wawancara dan data hasil observasi yang telah ditanskrip kemudian dipetakan berdasarkan kategori tema penelitian, data hasil reduksi tersebut penulis deskripsikan di deskripsikan serta digambarkan dalam bentuk narasi, tabel, maupun pola yang telah diverifikasi dalam hasil penelitian. Hasil penelitian yang dimaksud kemudian dianalisis dengan membandingkan konsep serta teori yang relevan lalu disimpulkan menjadi sebuah kesimpulan hasil penelitian berupa model dan pola yang dapat diterapkan dalam mendukung komunikasi yang efektif.

\section{Hasil Penemuan dan Diskusi}

Komunikasi dalam konteks persidangan yang disebut sebagai communication in courtroom (Cowles \& Cowles, 2011; Farley et al., 2014) merupakan proses komunikasi yang melibatkan berbagai komponen komunikasi dalam persidangan. Aronson mengungkapan komponen komunikasi dimaksud setidaknya terdiri dari pelaku komunikasi, peran, pesan dan tujuan (Aronsson et al., 1987). Di Pengadilan Negeri Jakarta Pusat, komunikasi dalam persidangan melibatkan penegak hukum, terdakwa, korban, dan saksi yang saling berkomunikasi dalam konteks persidangan. Komunikasi yang dilakukan sebagai upaya penyelesaian perkara pidana melalui persidangan. Beberapa tahapan persidangan mulai dari tahap awal -tahap awal sidang agenda dakwaan- sampai pada tahap akhir persidangan -tahap akhir sidang agenda putusan-. Dalam praktik persidangan pidana dilakukan dengan tipe acara pemeriksaan singkat menurut pasal 205 dalam KUHP ialah kejahatan atau pelanggaran yang menurut penuntut umum pembuktian atau penerapan hukumnya mudah dan sifatnya sederhana dan acaman hukuman yang akan dijatuhkan tidak berat. Sebaliknya disebut pemeriksaan biasa.

Di Pengadilan, setiap tahap persidangan pidana memiliki agenda, mulai dari agenda sidang pertama (sidang dakwaan), sidang pembuktian (agenda sidang pemeriksaan perkara), hingga sidang tuntutan dan sidang putusan. Dalam perkara terdakwa SK dengan kasus pidana biasa misalnya berlangsung 12 kali persidangan mulai dari agenda dakwaan, agenda pemeriksaan, agenda tuntutan dan agenda putusan. Agenda pemeriksaan berlangsung sebanyak 6 kali dengan memeriksa 
Aan Widodo: Model Komunikasi Pemeriksaan Dalam Sidang Agenda Pembuktian Perkara di Pengadilan

terdakwa, memeriksa korban, memeriksa saksi-saksi. Selain persidangan terdakwa SK juga terdapat persidangan lain yang memiliki tahapan yang sama dengan 4 kali persidangan dengan agenda pemeriksaan perkara terdakwa SN.

Dari sejumlah agenda persidangan yang dilakukan, salah satu yang menjadi inti dari persidangan adalah agenda pembuktian. Sebagaimana pandangan Samosir (2013) bahwa pemeriksaan perkara merupakan inti dari persidangan. Agenda pemeriksaan perkara menurut Informan $\mathrm{T}$ menjadi agenda pokok untuk membuktikan apakah terdakwa melakukan tindak kejahatan yang dituduhkan atau tidak, sejauh mana ia melakukan tindak kejahatan, hingga mengetahui sejauh mana keterlibatan terdakwa dalam tindak kejahatan yang dilakukan. Informan Y juga menguraikan bahwa dalam agenda pemeriksaan perkara terdapat 3 sudut pandangan yang diperoleh dari pemeriksaan yang dipetakan dari sumber informasi, misalnya dari sudut pandang korban sebagai orang yang dirugikan, dari sudut pandang terdakwa sebagai orang yang diduga melakukan kejahatan, hingga dari sudut pandang saksi sebagai orang yang dianggap terlibat juga mengetahui tindak pidana yang dilakukan terdakwa. Informasi ini diperoleh melalui proses komunikasi yang terjadi dalam setiap tahap persidangan. Pentingnya komunikasi dilakukan sebagaimana diungkapkan oleh Cowles (2011) bahwa komunikasi yang dilakukan berdampak pada putusan, persepsi pihak yang terlibat. Pun di Pengadilan, komunikasi dilakukan sebagai upaya penegakan hukum, melalui komunikasi akan diketahui apa tindak kejahatan benar-benar ada, apakah benarbenar dilakukan terdakwa, dan korban serta saksi menyaksikan tindakan yang dilakukan, serta alasan-alasan terdakwa melakukan tindak kejahatan, yang ditemukan dalam agenda pemeriksaan.

Komunikasi dalam sidang agenda pembuktian perkara yang oleh Matoesian (2017), Grażyna Anna Bednarek (2014) Joanne Morrison, Rachel Forrester-Jones, Jill Bradshaw, Glynis Murphy (2019) disebut komunikasi pemeriksaan (communication examination) (Bednarek, 2014; Matoesian, 2017; Morrison et al., 2019) melibatkan penegak hukum, terdakwa, korban, saksi, hingga pengunjung yang berkomunikasi baik secara verbal maupun nonverbal. Di Pengadilan Negeri Jakarta Pusat, komunikasi pemeriksaan tergambar dari proses komunikasi dalam sidang agenda pembuktian perkara, dimana dalam agenda tersebut terjadi komunikasi pemeriksaan terdakwa, komunikasi pemeriksaan korban, komunikasi pemeriksaan saksi oleh penegak hukum.

Sebagai sebuah konteks komunikasi dalam pembuktian perkara, komunikasi yang terjadi dalam agenda pemeriksaan perkara yang dilakukan penegak hukum dengan terdakwa, korban maupun saksi melalui interview dalam persidangan merupakan wujud dari komunikasi pemeriksaan (Bednarek, 2014; Field., 2018; Gehl \& Plecas, 2016; Matoesian, 2017; Roberts, 2011). Komunikasi yang dilakukan dalam agenda persidangan dilakukan secara bersama sama oleh penegak hukum. Komunikasi pemeriksaan berlangsung melibatkan penegak hukum, terdakwa, korban, hingga saksi sebagai pihak yang memiliki tujuan yang sama, yakni pemeriksaan perkara secara terus menerus akan melahirkan sebuah pola komunikasi. Meski memiliki tujuan sebagai kelompok yang sama, namun masing-masing pihak memiliki peran dan kepentingan yang berbeda. 
Tujuan Pemeriksaan perkara bagi terdakwa dan korban sebagai upaya mencari kebenaran dan memperoleh keadilan. Sementara bagi penuntut umum, pembuktian dilakukan sebagai upaya meyakinkan hakim bahwa terdakwa bersalah sesuai dengan dakwaan, sementara bagi terdakwa dan penasihat hukum, pembuktian sebagai upaya sebaliknya, meyakinkan hakim berdasarkan alat bukti, agar terdakwa dibebaskan dari tuntutan atau meringankan hukuman pidana. Bagi hakim, pembuktian merupakan dasar untuk membuat keputusan, yang disampaikan pada akhir persidangan (Hiariej, 2012). Berdasarkan hasil observasi dan keterangan yang disampaikan informan bahwa setidaknya dalam agenda pembuktian dilakukan dengan menggali semua informasi yang diperoleh dari alat bukti yang akan dihadirkan dari masing-masing pihak. Bukti diperoleh dengan dukungan komunikasi yang dilakukan.

Komunikasi yang terjadi dalam agenda pembuktian perkara setidaknya dapat diklasifikasikan menjadi komunikasi penegak hukum dalam memeriksa korban, komunikasi penegak hukum dalam memeriksa saksi, serta komunikasi terdakwa dalam memeriksa terdakwa. Upaya komunikasi yang dilakukan ini merupakan bagian dari komunikasi pemeriksaan. Sebagaimana yang terjadi dalam sidang terdakwa JS penegak hukum memeriksa korban dalam persidangan selama 30 menit dilanjutkan dengan memeriksa saksi dan korban pada hari yang sama namun agenda yang berbeda.

Komunikasi pemeriksaan terjadi melalui interview dan interogasi. Gambaran tersebut terjadi dalam proses tanya jawab antara partisipan dalam persidangan. Ketika observasi penulis pada saat persidangan di ruang sidang. Tanya jawab dilakukan guna mengkonfirmasi unsur perkara, mendapatkan informasi atau baru, keterangan penguat yang dibutuhkan masing-masing pihak. Informan $\mathrm{K}$ selaku penasihat hukum memberikan contoh bahwa ketika ia menangani klien yang didakwa melakukan pembunuhan dengan senjata tajam pisau, ketika penuntut umum menunjukkan pisau sebagai barang bukti, ketika ditanyakan apakah terdakwa melakukan dengan pisau yang dimaksud namun ternyata bukan, hanya saja penuntut umum menemukan pisau tersebut terkena tetesan darah korban yang diselamatkan. Bentuk tanya jawab dalam pemeriksaan terdakwa dilakukan untuk menggali informasi, menemukan informasi baru, mengkonfirmasi.

Keberlangsungan komunikasi pemeriksaan dalam persidangan yang dilakukan secara terus menerus membentuk suatu model komunikasi. Model ini terbentuk didasarkan pada kebiasaan yang di lakukan dalam persidangan yang terkandung berbagai komponen komunikasi (Haryono, 2015; Kuswarno, 2011), dalam konteks komunikasi pemeriksaan berbagai komponen komunikasi yang terkandung diantaranya terdapat pelaku komunikasi, pesan komunikasi dan tujuan komunikasi. Berikut model komunikasi pemeriksaan perkara dalam persidangan yang ditemukan dalam sidang agenda pemeriksaan perkara di pengadilan:

\section{Model Komunikasi Pemeriksaan dalam Persidangan}

Ketika agenda sidang pemeriksaan dimulai, hakim ketua membuka persidangan dengan membacakan agenda persidangan sesuai dengan ketentuan tahapan persidangan. Sesuai agenda dibacakan maka tahapan komunikasi pemeriksaan korban, pemeriksaan terdakwa dan pemeriksaan saksi dimulai. Sidang 
Aan Widodo: Model Komunikasi Pemeriksaan Dalam Sidang Agenda Pembuktian Perkara di Pengadilan

Agenda pemeriksaan perkara di ruang sidang pengadilan Negeri Jakarta Pusat melibatkan penegak hukum, saksi, terdakwa dan korban sebagai satu kesatuan dalam konteks komunikasi. Aktivitas komunikasi yang dilakukan dalam sidang agenda pemeriksaan disebut sebagai komunikasi pemeriksaan (communication examination) dapat dipetakan menjadi beberapa pola atau model komunikasi. Pemetraan model atau pola ini didasarkan pada kriteria communication examination.

Secara umum persidangan dan sidang agenda pembuktian perkara menunjukkan bahwa komunikasi pemeriksaan terjadi dalam persidangan di Pengadilan, berdasarkan kriteria Communication examination (Bednarek, 2014; Field., 2018; Gehl \& Plecas, 2016; Matoesian, 2017; Roberts, 2011) sebagai berikut: Komunikasi pemeriksaan terjadi di ruang persidangan, didasarkan pada kategori pelaku komunikasi, kepentingan, serta sumber informasi. Berdasar kategori pelaku, komunikasi terjadi antara penegak hukum dengan korban dalam agenda pemeriksaan korban, komunikasi penegak hukum dengan saksi dalam agenda pemeriksaan saksi, serta penegak hukum dengan terdakwa, dalam agenda pemeriksaan terdakwa. Sementara berdasarkan kepentingan, komunikasi pemeriksaan dalam ruang persidangan dilakukan dengan beragam tujuan, misalnya hakim berupaya menemukan bukti dengan memeriksa perkara, penasihat hukum berupaya membuktikan terdakwa dengan menghadirkan bukti dan saksi yang mendukung, sementara penuntut umum memiliki upaya sebaliknya berupaya membuktikan bahwa terdakwa bersalah telah melakukan tindak kejahatan. Berdasar sumber informasi dari sudut pandang korban sebagai orang yang dirugikan, dari sudut pandang terdakwa sebagai orang yang diduga melakukan kejahatan, hingga dari sudut pandang saksi sebagai orang yang dianggap terlibat juga mengetahui tindak pidana yang dilakukan terdakwa.

Komunikasi pemeriksaan yang dilakukan menjadi penting, sebab hasil dari pertukaran komunikasi yang dilakukan yang disebut "hasil pemeriksaan" di gunakan sebagai rujukan pertimbangan hakim dan penegak hukum menjatuhkan hukuman pada terdakwa. Ketika terdakwa dalam persidangan tidak mengakui kesalahan yang dilakukan dengan terdakwa lain yang mengakui kesalahan yang dilakukan, memiliki hukuman yang berbeda. Hal ini menunjukkan bahwa hasil pemeriksaan menjadi rujukan dalam pertimbangan hukuman yang diberikan.

Komunikasi pemeriksaan berlangsung dalam agenda pembuktian perkara, sebagaimana agenda pembuktian perkara dalam sidang terdakwa JS, SN dan terdakwa SK berlangsung dengan berbagai dukungan aspek komunikasi, baik secara individu maupun secara kelompok dengan alur atau pola yang biasa dilakukan, pola tersebut apabila diuraikan dalam wujud model komunikasi pemeriksaan sebagai berikut:

a. Model komunikasi antara penegak hukum dengan terdakwa.

Model komunikasi penegak hukum dengan terdakwa terjadi dalam sidang agenda pemeriksaan terdakwa. Komunikasi ini terjadi dalam bentuk interview atau interogasi yang dimulai dari tanya jawab hakim dengan terdakwa, kemudian secara bergiliran penasihat hukum dan penuntut umum melakukan upaya tanya jawab kepada dengan terdakwa. Berikut bentuk komunikasi yang terjadi. 
Panitera

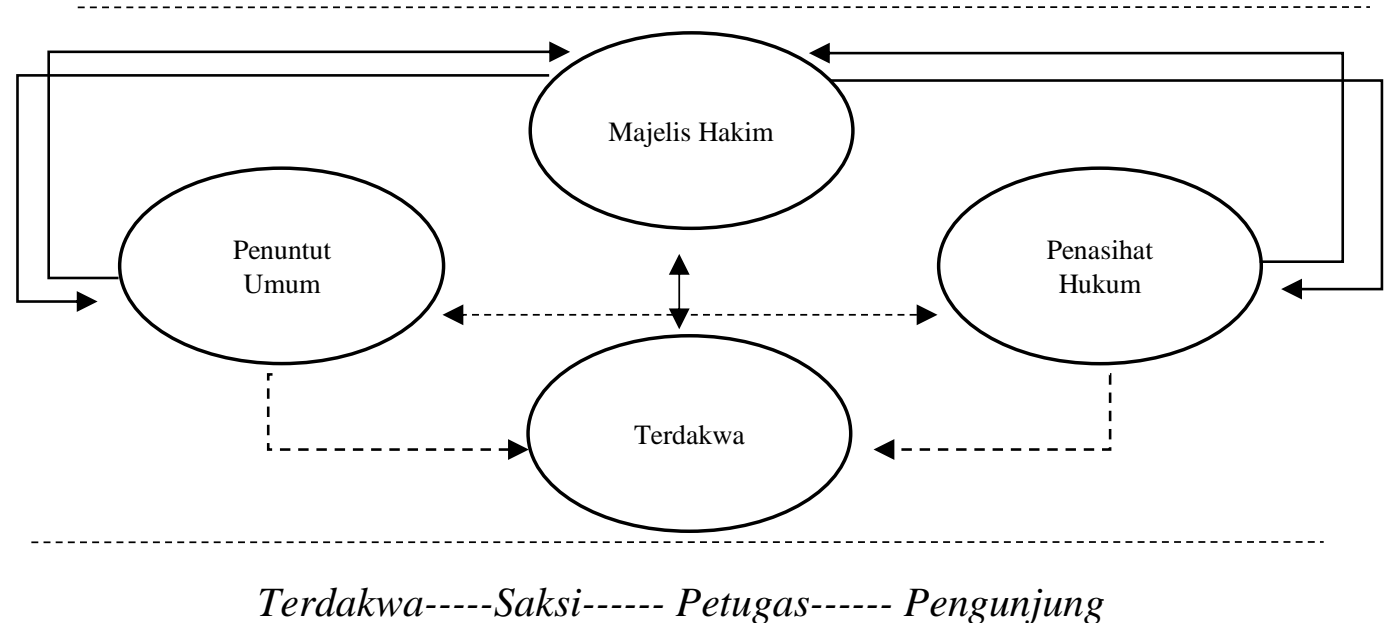

Gambar 1: Model Komunikasi Penegak Hukum dengan Terdakwa Sumber: Hasil Penelitian, 2020

b. Model komunikasi antara penegak hukum dengan korban.

Korban adalah salah satu partisipan yang terlibat dalam komunikasi pemeriksaan. Keterangan korban menjadi bagian inti dalam pembuktian perkara. Ketika komunikasi berlangsung, apa yang disampaikan korban menjadi sumber informasi, sebagaimana yang disampaikan informan J. Ketika di persidangan, kunci utama pemeriksaan ada pada korban.

Komunikasi ini juga terjadi dalam bentuk interview atau introgasi yang dimulai dari tanya jawab hakim dengan korban, kemudian secara bergiliran penasihat hukum dan penuntut umum melakukan upaya tanya jawab kepada korban.

Berikut bentuk model komunikasi yang terbentuk:

Panitera

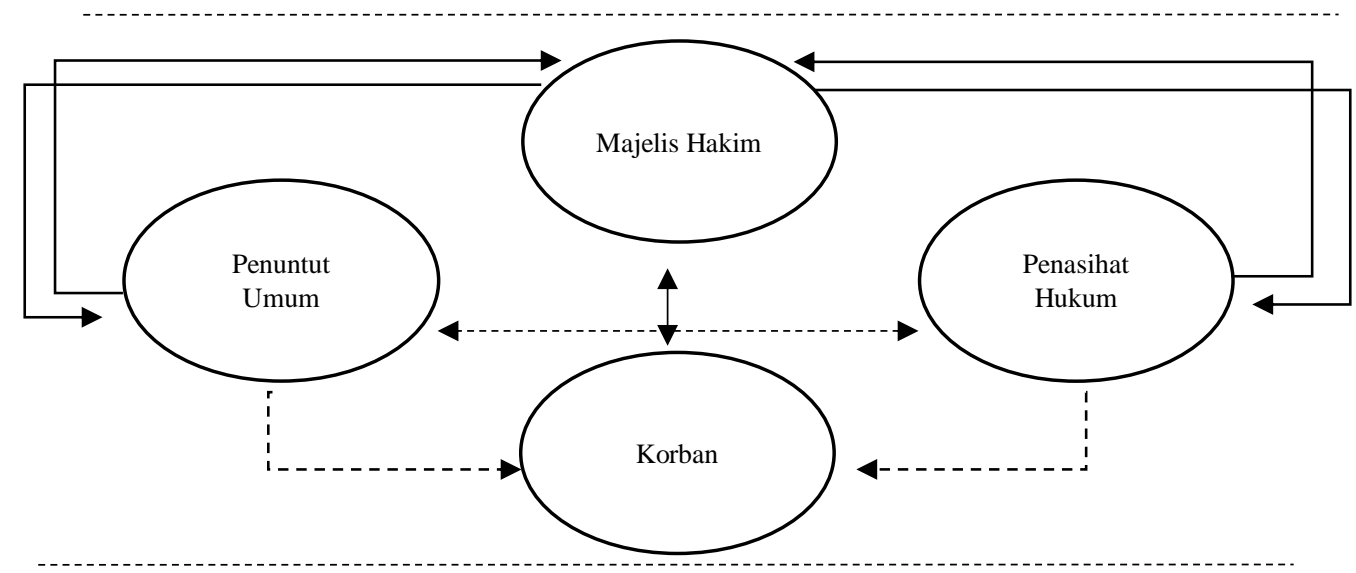

Saksi------Terdakwa------ Petugas------ Pengunjung

Gambar 2: Model Komunikasi Penegak Hukum dengan Korban

Sumber: Hasil Penelitian, 2020 
Aan Widodo: Model Komunikasi Pemeriksaan Dalam Sidang Agenda Pembuktian Perkara di Pengadilan

c. Model komunikasi antara penegak hukum dengan saksi.

Model komunikasi penegak hukum dengan saksi terjadi dalam sidang agenda pemeriksaan Saksi. Komunikasi ini terjadi dalam bentuk interview atau introgasi yang dimulai dari tanya jawab hakim dengan saksi, kemudian secara bergiliran penasihat hukum dan penuntut umum melakukan upaya tanya jawab kepada Saksi. Dalam praktiknya, saksi dalam persidangan dihadirkan oleh kedua belah pihak, yakni pihak penuntut umum dan pihak penasihat hukum, atau lazim disebut saksi yang meringankan terdakwa (saksi dari pihak terdakwa) dan saksi yang memberatkan terdakwa (saksi dari pihak korban)

Proses komunikasi berlangsung untuk menggali keterangan saksi berkaitan dengan apa yang dilihat atau diketahui saksi terkait perkara terdakwa, atau dengan keterangan saksi berkaitan dengan pengetahuan atau kepakaran saksi pada bidang tertentu. Komunikasi saksi dengan penegak hukum melibatkan berbagai bentuk pesan dalam bentuk proses tanya jawab. Tanya jawab dilakukan kepada dua klasifikasi saksi yang meringankan terdakwa dan saksi yang memberatkan terdakwa. Sebagaimana diurai dalam model berikut:

\section{Panitera}

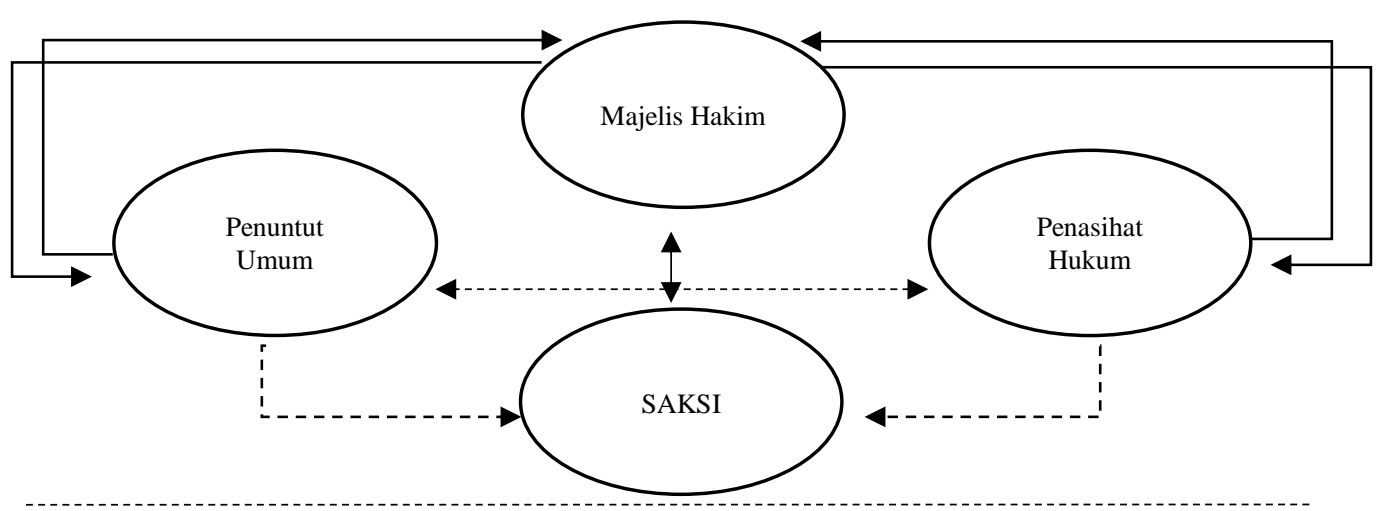

Terdakwa----- Korban------ Petugas------ Pengunjung

Gambar 3: Model Komunikasi Penegak Hukum dengan Saksi

Sumber: Hasil Penelitian, 2020

Di dasarkan pada model komunikasi yang terbentuk diatas, model-model tersebut dilakukan dengan beragam tujuan, kepentingan, dan kompetensi komunikasi yang berbeda. Komunikasi dalam ketiga model tersebut dalam praktiknya dapat dilakukan atau berlangsung secara terpisah, dan juga dapat berlangsung dalam agenda yang sama atau dilakukan dalam satu konteks yang sama. Dalam pandangan komunikasi, model ini disebut komunikasi pemeriksaan silang (cross-examanitaion communication). 


\section{Model Komunikasi pemeriksaan silang dalam persidangan}

Komunikasi pemeriksaan perkara, melibatkan penegak hukum dalam proses persidangan. Dalam persidangan terdapat professional hukum sebagai penegak hukum. Terdapat dua istilah yang sering muncul pada saat wawancara ketika bicara mengenai persidangan, yakni mengenai penegakan hukum dan penegak hukum. Dua hal ini dipandang berbeda. Penegakan hukum fokus kepada proses dan tujuannya-tujuan yang dimaskud adalah hukum yang tegak atau adilatau keadilan yang diharapkan, sementara penegak hukum adalah orang yang akan melakukan pencapaian tujuan itu atau aktor komunikasi atau pelaku komunikasi yang memilik tujuan dan kepentingan masing-masing guna mencapai hukum yang tegak.

Komunikasi pemeriksaan silang, berarti bentuk komunikasi yang dilakukan dalam pemeriksaan perkara secara silang, artinya ketika agenda memeriksa terdakwa dilakukan, saat yang sama saksi ataupun korban dihadirkan dalam agenda yang sama. Singkatnya komunikasi yang dilakukan oleh penegak hukum dalam agenda memeriksa keterangan ataupun bukti-bukti dilakukan dalam waktu yang sama. Hal ini dilakukan, selain mempersingkat proses juga mengkonfirmasi dan mengklarifikasi alat bukti atau keterangan yang dihasilkan dalam siang. Informan $\mathrm{H}$ menjelaskan bahwa pemeriksaan silang dilakukan ketika menggali informasi ataupun alat bukti pada masing-masing terdakwa, saksi ataupun korban ditemukan perbedaan secara substantif, misalnya terdakwa menyangkal bahwa melakukan tindak kejahatan, akan tetapi saksi menyatakan bahwa terdakwalah yang melakukan tindak kejahatan tersebut. Pemeriksaan silang ini lebih mengarah pada mengkonfrontasi keterangan dari satu sumber informasi dan di cek atau diverifikasi dengan alat bukti atau keterangan yang lain pada satu agenda sidang pembuktian perkara.

Aktivitas komunikasi pemeriksaan silang dalam agenda memeriksa korban, terdakwa ataupun saksi berdasarkan pelaku peran dan tujuan memiliki kesamaan dengan komunikasi pemeriksaan pada masing-masing model. Sehingga berdasarkan observasi peneliti, model komunikasi yang terbentuk dalam proses penegakan hukum dengan model komunikasi penegak hukum dengan terdakwa serta saksi maupun korban sebagai berikut: 


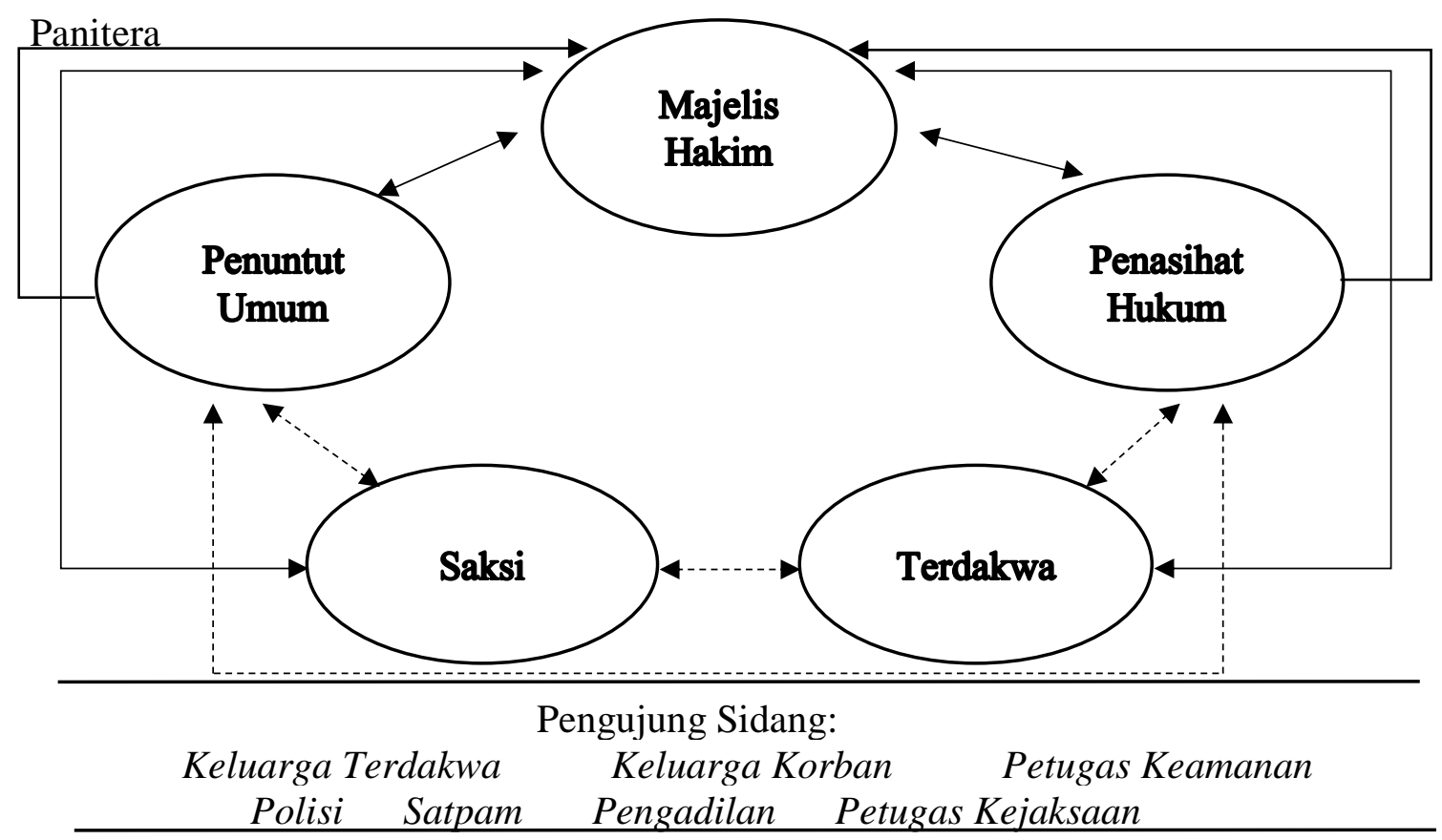

\section{RUANG SIDANG}

Gambar 4: Model Komunikasi Penegak Hukum dengan Terdakwa atau Saksi, dan Korban

Sumber: Hasil Penelitian, 2020

Keterangan:

Merupakan wujud dari interaksi langsung

Merupakan wujud Interaksi tak langung

Model komunikasi pemeriksaan (Comunication Examination) dan Komunikasi pemeriksaan silang (Cross-Communications Examination) diatas merupakan bentuk komunikasi yang terjadi dalam agenda pemeriksaan perkara pidana di pengadilan. Kedua model tersebut memiliki berbagai komponen komunikasi merujuk pada etnografi komunikasi Dell Hymes dan identifikasi komponen komunikasi pemeriksaan yang diuraikan dalam tabel berikut: 
Tabel 1. Komponen Komunikasi dalam Komunikasi Pemeriksaan

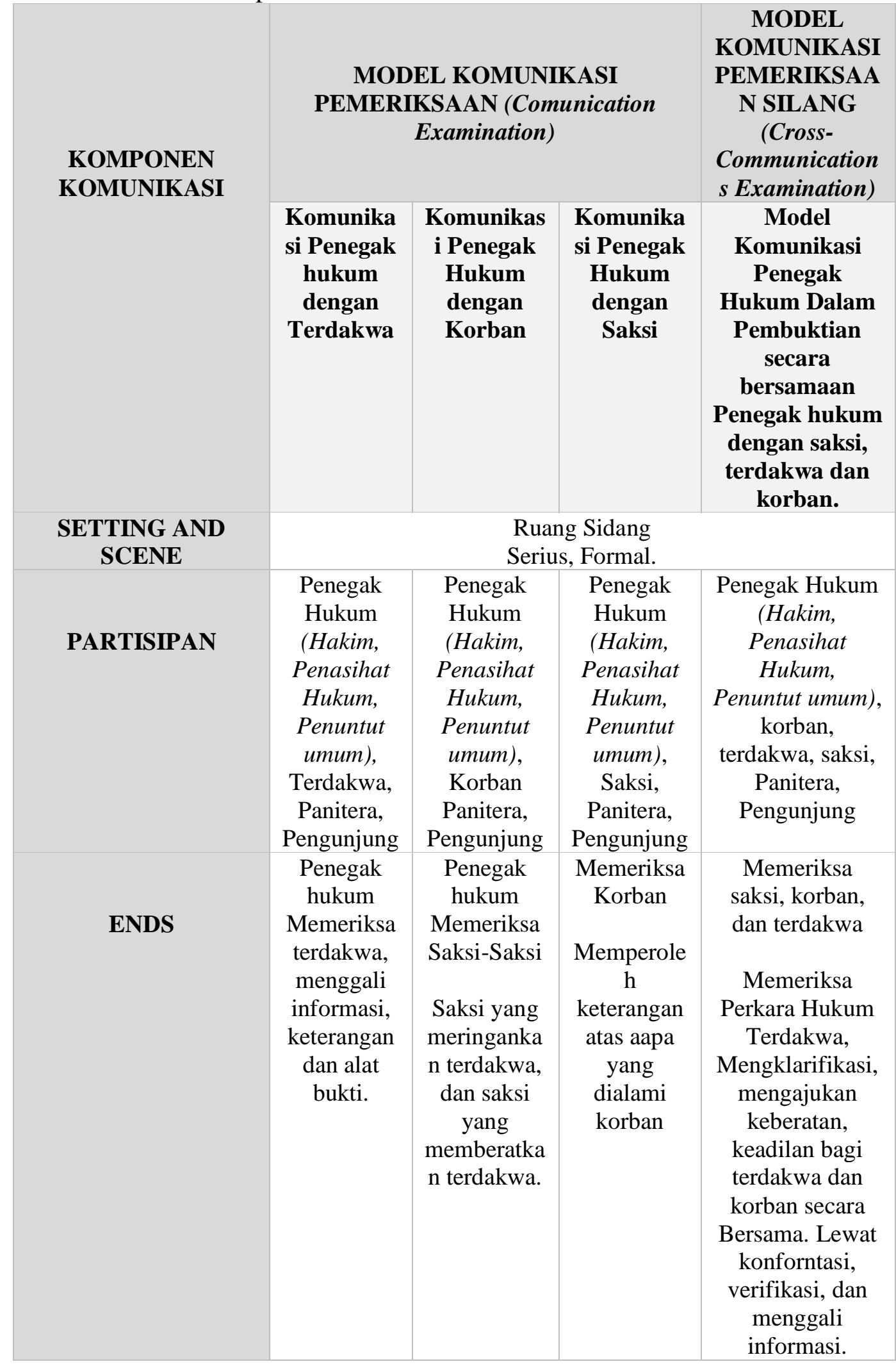




\begin{tabular}{|c|c|}
\hline ACT & $\begin{array}{c}\text { Pernyataan, Permohonan, Pertanyaan, permohonan, perintah, } \\
\text { tanya jawab, permintaan, penyangkalan, }\end{array}$ \\
KEY & $\begin{array}{c}\text { Nada Bicara Tinggi, Emosi, Tegas, nada marah, nada } \\
\text { kesedihan, }\end{array}$ \\
\hline $\begin{array}{c}\text { INTRUMENTALITI } \\
\text { ES } \\
\text { NORM }\end{array}$ & $\begin{array}{c}\text { Komunikasi Lisan dan komunikasi Tulisan, komunikasi } \\
\text { verbal dan nonverbal. }\end{array}$ \\
\hline GENRE & $\begin{array}{c}\text { Kuhap, Ketentuan Persidangan, Norma Interaksi, Norma } \\
\text { Kejujuran, Norma Interaksi, Norma Kesopanan, }\end{array}$ \\
\hline Tanya Jawab dan Jawab Menjawab, Interview, Interogasi \\
\hline
\end{tabular}

Sumber: Hasil Penelitian, 2020.

Tabel diatas, mengklasifikasi beda antara model komunikasi pemeriksaan (examination communication) dengan model komunikasi pemeriksaan silang (communication cross-examination communication) yang dilihat dari komponen komunikasi. Berdasarkan setting komunikasi yang merupakan pengaturan ruang dan fisik tempat terjadinya komunikasi. Berdasarkan definisi tersebut, maka setting komunikasi pemeriksaan terjadi dalam ruang sidang pengadilan, sebagaimana karakteristik komunikasi pemeriksaan. Sementera scene, yaitu suasana terjadinya komunikasi dalam pemeriksaan. Suasana yang terjadi dalam ruangan tergambar dilakukan secara serius, formal, dan ada batasan-batasan baik batasan lokasi maupun batasan suasana. Diantaranya saat sidang berlangsung, tidak diperkenankan terdakwa berpindah tempat duduk sebelum diperintahkan hakim majelis, tidak hanya terdakwa melainkan partisipan persidangan yang lain.

Dalam ruang sidang, terdapat partisipan yang saling berkomunikasi, terdiri dari pelaku sebagai pemberi dan penerima pesan yang membawa tujuan masingmasing, baik secara kelompok maupun secara individu. Berdasarkan observasi, partisipan dalam persidangan secara umum terdiri dari perwakilan pengadilan (hakim, panitera, petugas keamanan), pihak perwakilan kejaksaan (penuntut umum/jaksa, dan saksi dari penuntut umum) perwakilan kepolisian (petugas kepolisian), terdakwa dan penasihat hukum serta saksi, korban, serta pengunjung sidang. Dalam persidangan pemeriksaan perkara, partisipan menyesuaikan dengan konteks pemeriksaan, dimana keterlibatan seluruh partisipan dibatasi oleh agenda pemeriksaan, misalnya ketika agenda pemeriksaan terdakwa, maka yang terlibat didalamnya adalah penegak hukum dengan terdakwa. Begitu juga pemeriksaan saksi, maka yang terlibat adalah terdakwa dan saksi, baik saksi dari pihak penuntut umum maupun saksi dari penasihat hukum

Setiap partisipan, berdasarkan konteksnya memiliki tujuan, sehingga tujuan tersebut dicapai melalui komunikasi. Adapun secara umum tujuan komunikasi dalam pemeriksaan dilakukan adalah demi keadilan bagi terdakwa ataupun korban, yang secara spesifik memiliki tujuan masing-masing. Misalnya penasihat hukum berupaya membuktikan terdakwa tidak bersalah atau memperoleh hukuman yang ringan, saksi menyampaikan keterangan yang diketahui, baik saksi ahli maupun saksi korban. Tujuan komunikasi dicapai melalui berbagai tindakan komunikasi, dalam penyampaian informasi partisipan persidangan disampaikan melalui beragam cara, ada yang dengan mengeluarkan pernyataan, ada yang mengeluarkan permohonan, ada yang mengeluarkan perintah, ada yang mengungkapkan permintaan. Gaya penyampaian ini mencerminkan, posisi dalam persidangan, 
dimana tindakan komunikasi paling banyak dimiliki oleh hakim majelis, sementara paling sedikit dimiliki oleh saksi. Hakim dapat bertanya, memerintah, meminta, hingga menyatakan, sementara saksi dan terdakwa hanya dapat menjawab dan memberikan informasi. Tindakan komunikasi partisipan dalam persidangan disampaikan dengan beragam situasi yang tercermin dalam gaya atau cara penyampaian. Nada pesan yang disampaikan tercermin dari pernyataan, pertanyaan, perintah atau permohonan yang disampaikan selama pemeriksaan berlangsung. Tindakan yang sampaikan dalam pemeriksaan perkara oleh partisipan persidangan dibatasi oleh berbagai aturan, baik aturan yang tertulis secara langsung maupun tidak, beberapa aturan dinyatanya KUHP, dan berbagai norma, yaitu norma kejujuran, kesopanan, hingga norma interaksi. Proses tersebut berlangsung tanya jawab yang melahirkan konstruksi berdasarkan cerita atau keterangan yang disampaikan oleh masing-masing partisipan persidangan.

\section{Simpulan}

Sidang agenda pembuktian perkara dalam persidangan di pengadilan memunculkan dua model komunikasi pemeriksaan, pertama; yakni model komunikasi pemeriksaan terdiri dari (1) model komunikasi penegak hukum dengan terdakwa, (2) model komunikasi penegak hukum dengan korban, (3) model komunikasi pemeriksaan penegak hukum dengan saksi, kedua, yakni model komunikasi pemeriksaan silang. Penerapan kedua model ini dalam persidangan didukung oleh komponen komunikasi, dan kemampuan komunikasi, hasilnya dari komunikasi ini menjadi bahan pertimbangan masing-masing pihak dalam menentukan hukuman bagi terdakwa.

Penelitian ini bersifat deskriptif dan menemukan model komunikasi pemeriksaan dan komunikasi pemeriksaan silang dalam upaya penegak hukum dan didukung oleh berbagai faktor dan komponen komunikasi. Kemampuan komunikasi menjadi penting dalam pemeriksaan perkara. Sehingga, penelitian lebih lanjut diharapkan dapat mengukur kompetensi komunikasi dan efektivitas model komunikasi pemeriksaan dalam pembuktian perkara. Selain itu, model ini bisa dilanjutkan dengan pengujian efektivitas penerapan dalam persidangan, dan pijakan untuk menemukan alternative model komunikasi lainnya.

\section{Ucapan Terima Kasih}

Terima kasih dihaturkan kepada seluruh informan yang telah bersedia untuk memberikan keterangan berkaitan dengan topik penelitian ini, terutama pihak pengadilan Negeri Jakarta Pusat yang memberikan ijin riset, beserta penegak hukum dan perangkat persidangan yang memberikan keterangan. Tak lupa, ucapan terima kasih kepada pengelola editor, reviewer Jurnal Komunikasi Fakultas Ilmu Komunikasi Universitas Tarumanagara atas kesempatan publikasi karya ilmiah ini. Semoga karya ini dapat bermafaat bagi semua. 
Aan Widodo: Model Komunikasi Pemeriksaan Dalam Sidang Agenda Pembuktian Perkara di Pengadilan

\section{Daftar Pustaka}

Aceron, R. M. (2015). Conversational Analysis: The Judge and Lawyers ' Courtroom Interaction s. Asia Pacific Journal of Multidisciplinary Research, 3(5), 120-127.

Archer, D. (2011). Cross-examining lawyers, facework and the adversarial courtroom. Journal of Pragmatics, 43(13), 3216-3230. https://doi.org/10.1016/j.pragma.2011.06.007

Aronsson, K., Jönsson, L., \& Linell, P. (1987). The courtroom hearing as a middle ground: Speech accommodation by lawyers and defendants. Journal of Language and Social Psychology, 6(2), 99-115. https://doi.org/10.1177/0261927X8700600202

Bednarek, G. A. (2014). Polish vs. American Courtroom Discourse Inquisitorial and Adversarial Procedures of Witness Examination in Criminal Trials (1st ed.). Palgrave Macmillan.

Brewer, N., Vagadia, A. N., Hope, L., \& Gabbert, F. (2018). Interviewing witnesses: Eliciting coarse-grain information. Law and Human Behavior, 4(5), 458-471. https://doi.org/https://doi.org/10.1037/lhb0000294

Chen, J.-M. (2015). A Multimodal Study on Lawyer's Courtroom Communication Management. International Conference on Management Science and Management Innovation (MSMI 2015), Msmi, 267-271. https://doi.org/10.2991/msmi-15.2015.49

Cowles, K. M., \& Cowles, K. M. (2011). Communication in the Courtroom. Honors College and Center for Interdisciplinary Studies.

Creswell, J. W. (2010). Research design pendekatan kualitatif, kuantitatif, dan mixed. Pustaka Pelajar.

FĂRCAŞIU, M. (2013). The Ethnography of the Courtroom in American and Romanian Criminal Justice Systems. International Journal of Education and Research, 1(4), 1-8.

Farley, E. J., Jensen, E., \& Rempel, M. (2014). Improving Courtroom Communication: A Procedural Justice Experiment in Milwaukee. https://www.ncjrs.gov/App/AbstractDB/AbstractDBDetails.aspx?id=2665 79

Field., L. L. F. the. (2018). Investigating Violent Crime: The Prosecutor's Role Lessons Learned From the Field. Https://Crimegunintelcenters.Org, June. https://crimegunintelcenters.org/wp-

content/uploads/2018/09/Investigating-Violent-Crime-The-ProsecutorsRole-Lessons-Learned-from-the-Field-NRTAC-June-2018.pdf

Fuady, M. (2020). TEORI HUKUM PEMBUKTIAN PIDANA DAN PERDATA (Cetakan Ke). PT CITRA ADITYA BAKTI.

Gabbert, F., Hope, L., Carter, E., \& Fisher, R. (2015). ( 2015 ) Communicating with Witnesses: The role of initial accounts during investigative interviews. 271528351(August).

Gehl, R., \& Plecas, D. (2016). Introduction to Criminal Investigation : Processes, Practices and Thinking. 84-101. https://pressbooks.bccampus.ca/criminalinvestigation/chapter/chapter-7- 
witness-management/

Groome, D., \& Eysenck, M. (2016). An Introduction to Applied Cognitive Psychology (New York (ed.); 2nd ed.). Routledge. https://books.google.co.id/books/about/An_Introduction_to_Applied_Cog nitive_Psy.html?id=cTL7CwAAQBAJ\&redir_esc=y

Hadiprashada, D., Hadiprashada, D., Budiman, D. A., Bengkulu, U., Limun, K., \& Bengkulu, K. (2019). Komunikasi Lingkungan dalam Budaya Masyarakat ( Analisis Model Pesan Two Way Asymmetrical pada Lembaga Adat ). 213222.

Haryono, A. (2015). Etnografi Komunikasi: Konsep, Metode, dan Contoh Penelitian Pola Komunikasi. UPT Penerbitan UNEJ.

Hiariej, E. O. (2012). Teori dan Hukum Pembuktian. Erlangga.

Kebudayaan, K. P. dan. (2020). Persidangan. Https://Kbbi.Kemdikbud.Go.Id. https://kbbi.kemdikbud.go.id/entri/persidangan

Kristofer, I., \& Susanto, E. H. (2019). Pola Komunikasi Dalam Upacara Adat Teapai di Lingkup Etnis Tionghoa Jakarta. Koneksi, 2(2), 387-392.

Kuswarno, E. (2011). Etnografi Komunikasi (Cetakan 2). Widya Padjadjaran.

Littlejohn, S., \& Foss, K. A. (2009). Encyclopedia of Communication Theory. https://doi.org/10.4135/9781412959384

Matoesian, G. (2017). Communication in investigative and legal contexts: integrated approaches from forensic psychology, linguistics and law enforcement, edited by Gavin Oxburgh, Trond Myklebust, Tim Grant and Rebecca Milne. Police Practice and Research, 21(1), 95-96. https://doi.org/10.1080/15614263.2017.1283901

Morrison, J., Forrester-Jones, R., Bradshaw, J., \& Murphy, G. (2019). Communication and cross-examination in court for children and adults with intellectual disabilities: A systematic review. International Journal of Evidence and Proof, 23(4), 366-398. https://doi.org/10.1177/1365712719851134

Mulyana, D. (2017). METODE PENELITIAN KUALITATTIF : Paradigma Baru Ilmu Komunikasi dan Ilmu Sosial Lainnya. PT Remaja Rosdakarya.

Network, S. L. (2008). Self-Represented Litigation Network Effectiveness of Courtroom Communication in Hearings Involving Two Self-Represented Litigants An Exploratory Study. English.

R, Y. P. (2016). PUTUSAN HAKIM PADA PERKARA PIDANA: Kajian Psikologis. Buletin Psikologi, 3(1), 1-10. https://doi.org/10.22146/bpsi.13377

Roberts, A. (2011). Identification: Investigation, Trial and Scientific Evidence Paul Bogan , QC , and Andrew Roberts Book review by Sally Ramage, editor , The Criminal Lawyer. 2-3. http://www.criminallawyer.org.uk/Identification-book review-jordans 2011.pdf

Samosir, C. D. (2013). Segenggam tentang Hukum Acara Pidana. Nuansa Aulia.

Setyo, B. T. (2013). 済無No Title No Title. Journal of Chemical Information and Modeling, 53(9), https://doi.org/10.1017/CBO9781107415324.004

1689-1699. 
Aan Widodo: Model Komunikasi Pemeriksaan Dalam Sidang Agenda Pembuktian Perkara di Pengadilan

Widodo, A. (2019). Model Komunikasi Penegak Hukum dalam Ruang Persidangan di Pengadilan Negeri Jakarta Pusat. Jurnal Penelitian Komunikasi, 22(2), 139-154. https://doi.org/10.20422/jpk.v22i2.660

Widodo, A., Hidayat, D. R., Venus, A., \& Suseno, S. (2019). The pattern of interruption in Indonesia court room. International Journal of Recent Technology and Engineering, 8(2 Special Issue), 506-512.

Widodo, A., Rahmat Hidayat, D., Venus, A., \& Suseno, S. (2018). The Pattern of Communication Legal Advisor with Defendant In Indonesian Courtroom. International Journal of Engineering \& Technology, 7(3.30), 405. https://doi.org/10.14419/ijet.v7i3.30.18343 